\title{
Investigating Organizational Commitment among Medical Doctors, Hospital Nurses and Two Other Professional Jobs: A Systematic Review
}

\author{
Retno Setyowati ${ }^{1}$, Priyotomo ${ }^{1} \&$ Suharnomo ${ }^{1}$ \\ ${ }^{1}$ Department of Human Resource Management, Faculty of Economics and Business, Diponegoro University, \\ 50241, Semarang, Indonesia \\ Correspondence: Retno Setyowati, Faculty of Economics and Business, Diponegoro University, Semarang 50241, \\ Indonesia. Tel: 622-476-486-851; Fax: 622-476-486-852. E-mail: retnosetyo@fk.undip.ac.id
}

Received: July 3, 2017 Accepted: October 20, 2017 Online Published: October 24, 2017

doi:10.5539/gjhs.v9n12p99 URL: https://doi.org/10.5539/gjhs.v9n12p99

\begin{abstract}
This article describes the common characteristics of organizational commitment among professional jobs, such as medical doctors and hospital nurse, that have considerable important roles in creating company relationships with external parties. Those who work in these jobs bridge organizations and consumers on behalf of their companies, and are likely to bring in benefits to the development and achievement of organizational goals on one hand, and contrastly, also could be a harmful impact to the organization on the other hand. This study conceptually outlines the characteristics of organizational commitment among lawyers, accountants, and medical doctors. Results reveal some valuable considerations regarding organizational commitment in these professions.
\end{abstract}

Keywords: organizational commitment, medical doctors, external parties, organizational objectives, reward system

\section{Introduction}

The direction of current business developments lead to the ways used by an organization to improve their customers satisfaction, through placing the role of and focusing on human beings, either as employees or consumers. Accordingly, the human resource management aspect is increasingly important to analyze more deeply about the consequences of the commitment and perceptions of different employees toward the organisation. Human resources are considered a key source of innovation and strategy for organizations. The importance of human capital has led organizations and scholars alike, either practically or theoretically, to develop competitive human resources as a fundamental value of the organization (Ghorbanhosseini, 2013).

Organizational commitment is one of the most often analyzed variables in the literature of organizational management sciences. Many scholars are interested in this area since Meyer and Allen (1998) proposed a three-dimensional model of the construct. Since then, numerous studies on organizational commitment have emerged. Discussion of the commitment was no longer the impetus to become an employee or an employee being approached in an organization, but has become more on the emotional impulse of the profession the employees occupy in the organization where they work (Meyer \& Allen, 1998).

Many studies have widely discussed the organizational commitment of professional jobs, particularly of accountants (e.g., Lander, Koene, \& Linssen, 2013; Singh \& Gupta, 2015; Chong \& Monroe, 2015; Sejjaaka \& Kaawaase, 2014; Olsen, Sverdrup, Nesheim, \& Kalleberg, 2016; Welsch \& LaVan, 1981; Aranya \& Ferris, 1984; Morrow \& Wirth; 1989; Aranya \& Amernic, 1981; Reed, Kratchman, \& Strawser, 1994; Ketchand \& Strawser, 1998), nurses and hospital employees (e.g., Li, Early, Mahrer, Klaristenfeld, \& Gold, 2014; Top, Akdere, \& Tarcan, 2015; Fu \& Deshpande, 2014; Yang, Liu, Chen, \& Pan, 2014; Lisdiyono \& Asyhar Assalmani, 2017; Laschinger, Nosko, Wilk, \& Finegan, 2014; Nesje, 2015; Sharma \& Dhar, 2016; Veličković et al., 2014; Yang, Liu, Huang, \& Zhu, 2013; Blau, 1999; Mosadeghrad, Ferlie, \& Rosenberg, 2008; Lum, Kervin, Clark, Reid, \& Sirola, 1998; Ingersoll, Olsan, Drew-Cates, DeVinney, \& Davies, 2002; Kuokkanen, Leino-Kilpi, \& Katajisto, 2003; Lu, Lin, Wu, Hsieh, \& Chang, 2002), lawyers (e.g., Wallace, 1995a; Lu, Liang, \& Li, 2014), and teachers (Nart \& Batur, 2014; Bogler \& Somech, 2004). However, these studies only discussed the commitment of a particular professional job. In addition, there are only a few studies which have considered the commonalities between 
multiple occupations (e.g., Mathieu \& Zajac, 1990; Meyer, Allen, \& Smith, 1993). In this regard, this paper will further analyse this issue by comparing three professional areas and will give a more valuable summary of the results of previous studies in the relationship of organizational commitment and professional jobs. Moreover, this study is useful to address that further research should consider some different characteristics of a particular professional job that is profoundly distinguished from other kinds of jobs. Finally, this paper also provides a meta analysis that examines the commonalities of previous studies' statistical results, empirically providing a more established concept of professional job commitment.

\section{Organizational Commitment}

Commitment, which plays an important role in shaping the behavior of employees, and can be defined as the force that binds an individual to act, in accordance with the different perceptions that are relevant to the organizational goals (Meyer \& Herscovitch, 2001). Previous studies have specifically described the dimensions of organizational commitment (e.g., Meyer \& Herscovitch, 2001), and concluded that organizational commitment has a positive influence on the organization goals (Shagholi, 2011). In other words, high organizational commitment is assumed to produce high quality outcomes. However, some studies have not specifically discussed the jobs associated with external parties, they have only discussed organizational commitment from the degree of employee involvement in achieving organizational objectives, internal communication networks, and citizenship behaviors, where employees with high commitment are perceived to work beyond minimal job requirements and responsibilities.

The study of organizational commitment extends beyond employee loyalty, which implies the intention of the employee to stay and continue to work in the organization. Employees may work for an organization and exceed their material awareness and psychical and social benefits acquired in the internal environment of the organization. Organizational commitment arises when the goals and values of the organization have been identified by employees. Employees who are highly committed will voluntarily engage in jobs without questioning organizational rewards, and are more likely to empower their physical and material capabilities (Rusu, 2013; Balay \& Ipek, 2010).

Organizational commitment exists in every profession. This suggests that being able to predict the organizational development in the future depends heavily on human capital. In return, the organization in recent decades have been willing to provide high remuneration to maintain and enhance the commitment of their employees as well as offer more promising career advancement opportunities that can help maintain their human capital (Permarupan, 2013; Anggraeni, Dwiatmadja, \& Yuniawan, 2017). Organizations are becoming more dependent on committed employees to gain and maintain competitive advantage. This is reflected in recent organizational trends that consider the nature, development methods, and the implications of employee commitment (Meyer \& Parfyonova, 2010).

Managing employees who have an attachment to the organization is a difficult task for managers. Employees in the organization always have social interactions in their work environment and explore how their attitudes and behaviors fit into this environment (Dineen, Noe, Shaw, Duffy, \& Wiethoff., 2007). This two-way process seems to be already considered as an effective means in sustainable organizational development initiatives, but in some instances this is not entirely possible to achieve.

Negative effects can also arise from employee commitment in certain aspects. For example, affective commitment demonstrates a strong contribution to the organization's readiness for change. It means that an employee's connection to his or her organization may reflect different degrees which one may display commitment to the organization. Generally, the more employees feel attached to their organization, the more they will be committed to the organization and the more they are willing to embrace organizational change (Nordin, 2011). Nonetheless, continued commitment might negatively effect on areas of job satisfaction and performance (Namasivayam \& Zhao, 2007).

Studies regarding professional jobs show there is a positive relationship of employees belief and acceptance of goals and values of the profession on the willingness to incur the effort in the implementation of the profession and the desire to remain in the profession (Hall, Smith, \& Langfield-Smith, 2005; Purtilo, Haddad, \& Doherty, 2014; S. M. Kim, Um, H. Y. Kim, \& Y. H. Kim, 2016; Epstein, Seron, Oglensky, \& Saute, 2014; Purtilo \& Doherty, 2015). People generally feel willing to live better under a sense of stability. Decreasing and loosing the relationship of employee and organization is largely based on market conditions and organizational demands. When employees are touched by the positive stimuli and conditions that allow them to satisfy their needs, this fosters a development of increased organizational comitment. In this case, organizations need to maintain friendly conducive work conditions in order to preserve employee motivation (Bienkowska, 2012). Many aspects may effect an employee's attachment to an organization, such as organizational culture, emotional attention, job experience, age, gender, or 
office design. This highlights the conclusion that organizational commitment may affect individuals in different ways, depending on their type of profession.

\section{Organizational Commitment Among Lawyers, Accountants and Medical Doctors}

It is interesting to analyze the organizational commitment between professions. Optimizing multi-sectoral professions relies on the collaboration of program managers, human resource acquisition, and business and finance professionals (Kangas, 2009; Ghofur \& Susilo, 2017). When professionals work in a bureaucratic organization, they tend to feel conflicting goals and compelled to choose one loyalty over another. In such circumstances, they are often expected to be more committed to their profession rather than to the organization. Their job characteristics, which sometimes contact consumers or external parties find themselves in ambiguous situations. For instance, a lawyer who handles personal or organizational clients, or a medical doctor who is able to conduct clinical practice in hospitals, and accountants who are always linked to external parties rather than directly linked to the organization they work for. These professionals may have an attachment with their organization for matters which are not necessarily related to the achievement of the organization, beyond the individual investment. Meanwhile other professionals feel the organization's values, goals, and beliefs that could redirect their commitment (Rusu, 2013; Ghorbanhosseini, 2013; Gokce, Guney, \& Katrinli, 2014). Multi-sectoral professionals often work under different organizational cultures and structures.

Staff professionals often work under more stable and familiar conditions in relation to organizational objectives with established policies. Thus, they often feel they have a capacity to directly help the organizations that employ them. Loyalty to the organization seems to depend also on the professional opportunities for career advancement. For many lawyers, this motivation is the most important determinant of their professional commitment. Lawyers who work in non-professional organizations are generally less committed to their profession. The professional and non-professional organization are different in decision making relating their professional career advancement especially in the career promotion. These facts reveal that the level of organizational commitment among lawyers is often different for each type of organization (Wallace, 1995b).

Organizational commitment among finance professionals, such as accountants, are not directly related to the performance and results of the assessment involving stakeholders interests in the professional services, such as auditing. They generally work under a competitive environment that focuses on individual issues. Financial professionals tend to serve customers individually and build on the personal relationship between professionals and customers that often bind them in a deeper bond with the customer. This condition enables them to spend more time with customers and provides them with greater understanding of customer needs. Hence, organizations that employ financial professionals might face problems of employee commitment whether they are more likely to be committed to the organization or to the customers they serve. In this case, Furtmueller et al. (2011) suggested that organizations should invest more for permanent employees and establish long-term relationships with permanent employees. Organizations also need to create a bond with financial professionals who may be able to minimize conflicts of commitment and also provide competitive incentives for them (Furtmueller, 2011).

However, there are gender differences in organizational commitment among financial professionals (Mallon, 2003). Reed et al. (1994) stated that female accountants are generally less committed to organizations than are male accountants. Female accountants with their external orientation often feel less comfortable with their position in an organization, and are likely to intend to seek other opportunities outside. In addition, job experience positively relates to the level of one's organizational commitment. Having shorter job tenure is positively related to job satisfaction of women professionals and positively related to organizational commitment in men. Meanwhile, having a longer tenure is positively related to organizational commitment in women. The longer the tenure of an accountant, the longer they tend to stay with an organization. In this context, female accountants with primary external orientation are more likely to need high achievement and self-actualization.

Organizations need to provide ongoing appreciation, financial, and emotional support to their employees in order to keep retain them long term. In addition, some issues related to the physical environments also have a relationship with employee organizational commitment. For example, the redesign of an office environment is one factor that may increase the commitment of employees, who enjoy working in a comfortable environment. Comfort and attention provides an enabling environment that often encourages employees and help them feel like they want to stay longer in the office. As a result, organizational rewards of expressing appreciation for employees increases employee commitment (Morrow, 2012).

Meanwhile, some studies reveal that medical doctors have a low level of organizational culture. For example, doctors in Turkey hospital leadership patterns are closely associated with organizational culture patterns. But leadership behavior and organizational culture does not always affect their commitment to the organization. 
Findings from this study show that medical doctors' loyalty is not affected by the culture of the organization. Turkish doctors tend to work in private clinics outside working hours of their assigned hospitals. This is the reason for the low culture of the organization for hospital-based medical doctors. To overcome this situation, hospitals must establish full participation schemes among employees, by involving them in decision making processes, and delegating responsibilities within organization (Gokce et al., 2014). An effective participation scheme will prevent negative perceptions of medical doctors on hospital policies. This in turn will affect on increasing the level of organizational commitment. A study by Hoff and Mandell (2001) revealed dual executive commitment among doctors, and doctors found that executives are better able to balance both organizational and professional commitment. They show high organizational commitment when the work environment is comfortable and supportive. This dual commitment reflects job attitudes that encourage success in management roles, especially in increasing the comfort of the working environment, providing enough emotional support, and a high incentive for physicians.

Organizational commitment exists on every hierarchical level. People within organizations at every level of organizational commitment perceive things differently. Sisodia and Das (2013) study conducted in India revealed that among these differences, job autonomy significantly influences commitment. An organization that authorizes greater level of job autonomy is more likely to be trusted by their employees. Employees are able to manage their own schedules and are free to make decisions related to their job. Therefore, they feel greater appreciation toward their organizations, as compared to those with less autonomy and decision-making authority. However, employees with greater autonomy generally showed a higher level of commitment than if they were given less job autonomy. While the opposite was true for employees with less autonomy. Hence, autonomy is an important variable for decision makers especially for employees in more senior positions; it is less effective among employees at lower seniority levels in the organization (Sisodia \& Das, 2013).

Different combinations of multiple commitments have now become a challenging issue within many organizations. A study on employee commitment focused on a smaller division of the organization such as divisions, branches, and teams within the organization (Meyer et al., 1998). The different perspective of organizational commitment among employees of various professions might explain the need for establishing managerial policy. Managers tend to function better as the bridge between employees and the organization in achieving better performance and organizational goals. In assessing organizational commitment among different professionals, there is a need for assessing some different policies for each organization. In practical terms, this study reveals some implications that focuses on the development of managerial policies to increase employees' organizational commitments among professionals. An organization that employs lawyers should provide designated titles and job roles for them. Hence, professional management within organizations is an imperative task. For organizations with financial professionals, it is necessary to provide a blend of actions to improve the convenience of their work, decrease the number of contract employees for professionals jobs, and build ties between the organisation and employees emotionally. Hospitals need to build organizational culture, due to the fact that many doctors feel a lack of organizational culture, while nurses are generally more dependable with the organizational subculture. The leader's role is highly important in establishing appropriate organizational cultures and managerial policies. Finally, each organization must increase trust of their employees by providing a higher degree of job autonomy. Organizational culture needs to be strengthened in order to build a competitive environment among all employees.

\section{Conclusion}

This conceptual study reveals some important conclusions. Lawyer participants perceived their job status as the most important predictor to their commitment. Their loyalty often depends on their career development. Lawyers in non-professional institutions are generally less likely to show a lower level of organizational commitment. Hence, in this situation, organizations need to establish a competitive system of career development and ensure job status among lawyers.

Financial professionals tend to have a low degree of organizational commitment, due to the fact that they frequently focus on deep relationships with clients. In terms of gender, women accountants are generally less committed to organizations, and more externally oriented. For financial professionals, a comfortable working environment, emotional attention focus, and high incentives are important predictors of organizational commitment. And similar with lawyers in the same situation, financial workers generally have a low degree of commitment when temporarily employed.

The degree of organizational commitment of medical professions is closely linked to the behavior of leaders. Doctors generally consider that organizational culture and commitment are a lower-level priority. Organizational cultural conflicts tend to occur in the medical profession because they can work in more than one organization, or 
work in a private clinic or practice outside their contracted working hours.

\section{Competing Interests Statement}

The authors declare that there are no competing or potential conflicts of interest.

\section{References}

Anggraeni, A. I., Dwiatmadja, C., \& Yuniawan, A. (2017). The role of psychological contract on employee commitment and organisational citizenship behaviour: A study of Indonesian young entrepreneurs in management action. SA Journal of Industrial Psychology/SA Tydskrif vir Bedryfsielkunde, 43(0), a1409. https://doi.org/10.4102/sajip.v43i0.1409

Aranya, N., \& Ferris, K. (1984). A Reexamination of Accountants' Organizational-Professional Conflict. The Accounting Review, 59(1), 1-15. Retrieved from http://www.jstor.org/stable/247113

Aranya, N., Pollock, J., \& Amernic, J. (1981). An examination of professional commitment in public accounting. Accounting, Organizations and Society, 6(4), 271-280. https://doi.org/10.1016/0361-3682(81)90007-6

Balay, R., \& Ipek, C. (2010). Teachers' perception of organizational culture and organizational commitment in Turkish primary schools. Zeitschrift für die Welt der Türken/Journal of World of Turks, 2(1), 363-384. Retrieved from http://www.dieweltdertuerken.org/index.php/ZfWT/article/viewArticle/86

Bieńkowska, J. (2012). Organizational and professional commitment: The comparative study. Problems of Management in the 21st century, 4, 21-29. Retrieved from http://www.scientiasocialis.lt/pmc/files/pdf/Bienkowska_Vol.4.pdf

Blau, G. (1999). Early-career job factors influencing the professional commitment of medical technologists. Academy of Management Journal, 42(6), 687-695. https://doi.org/10.2307/256989

Bogler, R., \& Somech, A. (2004). Influence of teacher empowerment on teachers' organizational commitment, professional commitment and organizational citizenship behavior in schools. Teaching and teacher education, 20(3), 277-289. https://doi.org/10.1016/j.tate.2004.02.003

Chong, V. K., \& Monroe, G. S. (2015). The impact of the antecedents and consequences of job burnout on junior accountants' turnover intentions: a structural equation modelling approach. Accounting \& Finance, 55(1), 105-132. https://doi.org/10.1111/acfi.12049

Dineen, B. R., Noe, R. A., Shaw, J. D., Duffy, M. K., \& Wiethoff, C. (2007). Level and dispersion of satisfaction in teams: Using foci and social context to explain the satisfaction-absenteeism relationship. Academy of Management Journal, 50(3), 623-643. https://doi.org/10.5465/AMJ.2007.25525987

Epstein, C. F., Seron, C., Oglensky, B., \& Saute, R. (2014). The part-time paradox: Time norms, professional life, family and gender. Routledge.

Fu, W., \& Deshpande, S. P. (2014). The impact of caring climate, job satisfaction, and organizational commitment on job performance of employees in a China's insurance company. Journal of Business Ethics, 124(2), 339-349. https://doi.org/10.1007/s10551-013-1876-y.

Furtmueller, E., van Dick, R., \& Wilderom, C. P. (2011). On the illusion of organizational commitment among finance professionals. Team Performance Management: An International Journal, 17(5/6), 255-278. https://doi.org/10.1108/13527591111159009

Ghofur A., \& Susilo S. (2017). Maslaha as the Philosophical, Political, and Legal Basis on the Islamic Banking Legislation in Indonesia. Global Journal Al Thaqafah, 7(1), 7-17.

Ghorbanhosseini, M. (2013). The effect of organizational culture, teamwork and organizational development on organizational commitment: The mediating role of human capital. Tehnički vjesnik, 20(6), 1019-1025. Retrieved from http://hrcak.srce.hr/index.php?show=clanak\&id_clanak_jezik=165751.

Gokce, B., Guney, S., \& Katrinli, A. (2014). Does doctors' perception of hospital leadership style and organizational culture influence their organizational commitment?. Social Behavior and Personality: an international journal, 42(9), 1549-1561. https://doi.org/10.2224/sbp.2014.42.9.1549.

Hall, M., Smith, D., \& Langfield-Smith, K. (2005). Accountants' commitment to their profession: Multiple dimensions of professional commitment and opportunities for future research. Behavioral Research in Accounting, 17(1), 89-109. https://doi.org/10.2308/bria.2005.17.1.89

Harrison, J. K., \& Hubbard, R. (1998). Antecedents to organizational commitment among Mexican employees of a 
US firm in Mexico. The Journal of Social Psychology, 138(5), 609-623. https://doi.org/10.1080/00224549809600416

Hoff, T. J., \& Mandell, J. (2001). Exploring dual commitment among physician executives in managed care/Practitioner application. Journal of Healthcare Management, 46(2), 91-109.

Ingersoll, G. L., Olsan, T., Drew-Cates, J., DeVinney, B. C., \& Davies, J. (2002). Nurses' job satisfaction, organizational commitment, and career intent. Journal of Nursing Administration, 32(5), 250-263. https://doi.org/10.1097/00005110-200205000-00005

Kangas, P. J. (2009). Managing the multi-sector workforce through public management collaboration. Public Manager, 38(3), 45-51.

Ketchand, A. A., \& Strawser, J. R. (1998). The existence of multiple measures of organizational commitment and experience-related differences in a public accounting setting. Behavioral Research in Accounting, 10, 109-137.

Kim, S. M., Um, K. H., Kim, H. Y., \& Kim, Y. H. (2016). Hospital career management systems and their effects on the psychological state and career attitudes of nurses. Service Business, 10(1), 87-112. https://doi.org/10.1007/s11628-014-0257-7

Kuokkanen, L., Leino-Kilpi, H., \& Katajisto, J. (2003). Nurse empowerment, job - related satisfaction, and organizational commitment. Journal of nursing care quality, 18(3), 184-192.

Lander, M. W., Koene, B. A., \& Linssen, S. N. (2013). Committed to professionalism: Organizational responses of mid-tier accounting firms to conflicting institutional logics. Accounting, Organizations and Society, 38(2), 130-148. https://doi.org/10.1016/j.aos.2012.11.001

Laschinger, H. K. S., Nosko, A., Wilk, P., \& Finegan, J. (2014). Effects of unit empowerment and perceived support for professional nursing practice on unit effectiveness and individual nurse well-being: A time-lagged study. International journal of nursing studies, 51(12), 1615-1623. https://doi.org/10.1016/j.jnurstu.2014.04.010

Li, A., Early, S. F., Mahrer, N. E., Klaristenfeld, J. L., \& Gold, J. I. (2014). Group cohesion and organizational commitment: protective factors for nurse residents' job satisfaction, compassion fatigue, compassion satisfaction, and burnout. Journal of Professional Nursing, 30(1), 89-99. https://doi.org/10.1016/j.profnurs.2013.04.004

Lisdiyono, E., \& Asyhar Assalmani, M. N. B. (2017). Community Right to Health on Pharmaceutical Patents. International Journal of Civil Engineering and Technology, 8(7), 920-924.

Lu, H., Liang, B., \& Li, Y. (2014). Professional commitment and job satisfaction: An analysis of the Chinese judicial reforms from the perspective of the criminal defense. China Review, 14(2), 159-181.

Lu, K. Y., Lin, P. L., Wu, C. M., Hsieh, Y. L., \& Chang, Y. Y. (2002). The relationships among turnover intentions, professional commitment, and job satisfaction of hospital nurses. Journal of Professional Nursing, 18(4), 214-219. https://doi.org/10.1053/jpnu.2002.127573

Lum, L., Kervin, J., Clark, K., Reid, F., \& Sirola, W. (1998). Explaining nursing turnover intent: job satisfaction, pay satisfaction, or organizational commitment?. Journal of organizational behavior, 305-320. Retrieved from http://www.jstor.org/stable/3100174

Mathieu, J. E., \& Zajac, D. M. (1990). A review and meta-analysis of the antecedents, correlates, and consequences of organizational commitment. Psychological bulletin, 108(2), 171- 194. https://doi.org/10.1037/0033-2909.108.2.171

Meyer, J. P., \& Allen, N. J. (1997). Commitment in the workplace: Theory, research, and application. Thousand Oaks, CA: Sage.

Meyer, J. P., \& Herscovitch, L. (2001). Commitment in the workplace: Toward a general model. Human resource management review, 11(3), 299-326. https://doi.org/10.1016/S1053-4822(00)00053-X

Meyer, J. P., \& Parfyonova, N. M. (2010). Normative commitment in the workplace: A theoretical analysis and re-conceptualization. Human resource management review, 20(4), 283-294. https://doi.org/10.1016/j.hrmr.2009.09.001

Meyer, J. P., Allen, N. J., \& Smith, C. A. (1993). Commitment to organizations and occupations: Extension and test of a three-component conceptualization. Journal of applied psychology, 78(4), 538-551. 
https://doi.org/10.1037\%2F0021-9010.78.4.538

Meyer, J. P., Irving, P. G., \& Allen, N. J. (1998). Examination of the combined effects of work values and early work experiences on organizational commitment. Journal of organizational Behavior, 29-52. Retrieved from http://www.jstor.org/stable/3100226

Morrow, P. C., \& Wirth, R. E. (1989). Work commitment among salaried professionals. Journal of Vocational Behavior, 34(1), 40-56. https://doi.org/10.1016/0001-8791(89)90063-8

Morrow, P. C., McElroy, J. C., \& Scheibe, K. P. (2012). Influencing organizational commitment through office redesign. Journal of Vocational Behavior, 81(1), 99-111. https://doi.org/ 10.1016/j.jvb.2012.05.004

Mosadeghrad, A. M., Ferlie, E., \& Rosenberg, D. (2008). A study of the relationship between job satisfaction, organizational commitment and turnover intention among hospital employees. Health services management research, 21(4), 211-227. https://doi.org/10.1258/hsmr.2007.007015

Namasivayam, K., \& Zhao, X. (2007). An investigation of the moderating effects of organizational commitment on the relationships between work-family conflict and job satisfaction among hospitality employees in India. Tourism Management, 28(5), 1212-1223. https://doi.org/10.1016/j.tourman.2006.09.021

Nart, S., \& Batur, O. (2014). The relation between work-family conflict, job stress, organizational commitment and job performance: A study on Turkish primary teachers. European Journal of Research on Education, 2(2), 72-81. https://doi.org/10.15527/ejre.201426250

Nesje, K. (2015). Nursing students' prosocial motivation: does it predict professional commitment and involvement in the job?. Journal of advanced nursing, 71(1), 115-125. https://doi.org/ 10.1111/jan.12456

Nordin, N. (2011). The influence of emotional intelligence, leadership behaviour and organizational commitment on organizational readiness for change in higher learning institution. Procedia-Social and Behavioral Sciences, 29, 129-138. https://doi.org/10.1016/j.sbspro.2011.11.217

Olsen, K. M., Sverdrup, T., Nesheim, T., \& Kalleberg, A. L. (2016). Multiple foci of commitment in a professional service firm: balancing complex employment relations. Human Resource Management Journal, 26(4), 390-407. https://doi.org/10.1111/1748-8583.12109

Permarupan, P. Y., Saufi, R. A., Kasim, R. S. R., \& Balakrishnan, B. K. (2013). The Impact of Organizational Climate on Employee's Work Passion and Organizational Commitment. Procedia-Social and Behavioral Sciences, 107, 88-95. https://doi.org/10.1016/j.sbspro.2013.12.403

Pringle, J., \& Mallon, M. (2003). Challenges for the boundaryless career odyssey. International Journal of Human Resource Management, 14(5), 839-853. https://doi.org/10.1080/0958519032000080839

Purtilo, R. B., \& Doherty, R. F. (2015). Ethical dimensions in the health professions. Elsevier Health Sciences.

Purtilo, R. B., Haddad, A. M., \& Doherty, R. F. (2014). Health professional and patient interaction. Elsevier Health Sciences.

Reed, S. A., Kratchman, S. H., \& Strawser, R. H. (1994). Job satisfaction, organizational commitment, and turnover intentions of United States accountants: The impact of locus of control and gender. Accounting, Auditing \& Accountability Journal, 7(1), 31-58. https://doi.org/10.1108/09513579410050371.

Rusu, R. (2013). Affective Organizational Commitment, Continuance Organizational Commitment Or Normative Organizational Commitment?. Land Forces Academy Review, 18(2), 192-197.

Sejjaaka, K. S., \& Kaawaase, K. T. (2014). Professionalism, rewards, job satisfaction and organizational commitment amongst accounting professionals in Uganda. Journal of Accounting in Emerging Economies, 4(2), 134-157. https://doi.org/10.1108/JAEE-01-2012-0003.

Shagholi, R., Zabihi, M. R., Atefi, M., \& Moayedi, F. (2011). The consequences of organizational commitment in education. Procedia-Social and Behavioral Sciences, 15, 246-250. https://doi.org/10.1016/j.sbspro.2011.03.081.

Sharma, J., \& Dhar, R. L. (2016). Factors influencing job performance of nursing staff: mediating role of affective commitment. Personnel Review, 45(1), 161-182. https://doi.org/10.1108/PR-01-2014-0007

Singh, A., \& Gupta, B. (2015). Job involvement, organizational commitment, Professional commitment, and team commitment: A study of generational diversity. Benchmarking: An International Journal, 22(6), 1192-1211. https://doi.org/10.1108/BIJ-01-2014-0007 
Sisodia, S., \& Das, I. (2013). Effect of job autonomy upon organizational commitment of employees at different hierarchical level. Psychological Thought, 6(2), 241-251. https://doi.org/10.5964/psyct.v6i2.65

Top, M., Akdere, M., \& Tarcan, M. (2015). Examining transformational leadership, job satisfaction, organizational commitment and organizational trust in Turkish hospitals: public servants versus private sector employees. The International Journal of Human Resource Management, 26(9), 1259-1282. https://doi.org/10.1080/09585192.2014.939987

Veličković, V. M., Višnjić, A., Jović, S., Radulović, O., Šargić, Č., Mihajlović, J., \& Mladenović, J. (2014). Organizational commitment and job satisfaction among nurses in Serbia: A factor analysis. Nursing outlook, 62(6), 415-427. https://doi.org/10.1016/j.outlook.2014.05.003

Wallace, J. E. (1995). Corporatist control and organizational commitment among professionals: The case of lawyers working in law firms. Social Forces, 73(3), 811-840. doi: 10.1093/sf/73.3.811

Wallace, J. E. (1995). Organizational and professional commitment in professional and nonprofessional organizations. Administrative Science Quarterly, 228-255. Retrieved from http://www.jstor.org/stable/2393637

Welsch, H. P., \& LaVan, H. (1981). Inter-relationships between organizational commitment and job characteristics, job satisfaction, professional behavior, and organizational climate. Human Relations, 34(12), 1079-1089.https://doi.org/10.1177/001872678103401205

Yang, J., Liu, Y., Chen, Y., \& Pan, X. (2014). The effect of structural empowerment and organizational commitment on Chinese nurses' job satisfaction. Applied Nursing Research, 27(3), 186-191. https://doi.org/10.1016/j.apnr.2013.12.001

Yang, J., Liu, Y., Huang, C., \& Zhu, L. (2013). Impact of empowerment on professional practice environments and organizational commitment among nurses: A structural equation approach. International journal of nursing practice, 19(S1), 44-55. https://doi.org/10.1111/ijn.12016

\section{Copyrights}

Copyright for this article is retained by the author(s), with first publication rights granted to the journal.

This is an open-access article distributed under the terms and conditions of the Creative Commons Attribution license (http://creativecommons.org/licenses/by/4.0/). 